\title{
Fine needle aspiration cytology of cystic lesions of head and neck
}

\author{
Narendra Bhattarai ${ }^{1}$, Akanksha Kushwah ${ }^{2}$ \\ ${ }^{\prime}$ Department of Pathology, Grande International Hospital Pvt. Ltd, Kathmandu, Nepal \\ ${ }^{2}$ Institute of Medicine, Tribhuvan University teaching hospital, Kathmandu, Nepal
}

\section{Keywords: \\ Colloid; Cyst; \\ Tuberculosis; \\ Epidemoid; \\ Hemangioma; \\ Lymph node; \\ Thyroid}

\section{ABSTRACT}

Background: Many non-neoplastic and neoplastic lesions are encountered as cystic lesions of head and neck depending on the patient's age and anatomical site. Value of FNAC in preoperative diagnosis of these lesions has been established in various study.

Materials and Methods: The study was performed in 333 patients that presented as cystic lesions of head and neck at Department of Pathology, Tribhuvan University Teaching Hospital, Institute of Medicine, Kathmandu, Nepal from July 2013 to June 2014.

Results: Cystic lesions in head and neck accounted for $11.35 \%$ of all FNACs. The median age of the patients was 31 years and the majority of the patients were in the age group of 21-30 years with slight female predilection. Lateral neck was the most common site with lymph node (31.9\%) the most common organ of involvement. Tuberculous lymphadenitis was the most common diagnosis with $21 \%$ of cases, followed by colloid goiter with cystic change and epidermal cyst. Pus was the most common aspiration finding. Sensitivity and specificity of FNAC in diagnosing malignancy was $83.3 \%$ and $100 \%$ respectively

Conclusion: A significant number and wide variety of lesions present as cystic lesions of head and neck. FNAC is useful and cost effective tool to classify, diagnose and rule out malignancy in these cases.

\section{Correspondence:}

Dr. Narendra Bhattarai, $M B B S, M D$

Department of Pathology, Grande International Hospital Pvt. Ltd.,

Dhapasi, Kathmandu Nepal

ORCID ID: 0000-0002-8053-8622

Email: narenbhatrai@gmail.com

Reveived : March $30^{\text {th }} 2018$; Accepted : July 1 ${ }^{\text {st }} 2018$; Published : September $1^{\text {st }} 2018$

Citation: Bhattarai N, Kushwah A. Fine needle aspiration cytology of cystic lesions of head and neck. J Pathol Nep 2018;8:1360-4. DOI: 10.3126/jpn.v8i2.20874

Copyright: This is an open-access article distributed under the terms of the Creative Commons Attribution 4.0 International License, which permits unrestricted use, distribution, and reproduction in any medium, provided the original author and source are credited.

\section{INTRODUCTION}

A cyst is a swelling containing fluid or semisolid material. It is of two types: true and false cyst (pseudocyst). True cyst is lined by epithelium or endothelium while false cyst doesn't have any lining epithelium or endothelium. ${ }^{1}$ Cystic lesion in head and neck may originate from salivary glands or adjacent structures, such as lymph nodes, skin appendages, soft tissues or developmental abnormalities such as branchial clefts. ${ }^{2}$

Clinical examination alone is not able to distinguish benign from malignant lesions. ${ }^{3}$ 
Fine needle aspiration cytology (FNAC) is a rapid reliable and safe technique for differential diagnosis of head and neck lesions. It is simple, rapid and inexpensive. The main goal of FNA is to determine the presence or absence of neoplasm, assure the clinical benign impression of the mass, and if malignant, to determine the type of malignancy. ${ }^{2,4}$ Although FNAC has been proven effective in diagnosis of solid masses of head and neck, its usefulness in diagnosis of cystic masses in these sites is much less certain. ${ }^{5}$

Earlier study of patient with malignant cervical cysts has reported poor results for FNAC in detection of malignancy, with reported sensitivities ranging from $35 \%$ to $50 \%$. However, number of patients undergoing FNAC in each of these studies has been small. ${ }^{6}$ In a nutshell, FNA findings aid in initial evaluation of the lesion for taking subsequent steps in treating the lesions and managing the patients. Although FNA has a high diagnostic accuracy, several problems may arise, primarily affecting sensitivity of technique, especially if the aspirated mass is cystic. ${ }^{7}$

\section{MATERIALS AND METHODS}

This prospective descriptive study was carried out over a period of one year (April 14, 2013 to April 13, 2014) with a sample size of 333 cases at the Department of Pathology, Institute of Medicine, Tribhuvan University Teaching Hospital, Kathmandu, Nepal.

Approval of the study protocol by the Institutional Review Board of Institute of Medicine was obtained. FNAC was done using 23-25 guage needle and $10 \mathrm{ml}$ syringe and the smears were stained with Giemsa and papanicolaou stain. The histopathological specimen were fixed with formalin then processed routinely and stained with $\mathrm{H}$ and $\mathrm{E}$. The slides were reviewed by pathologist and diagnosis was made. Data analysis was done with Microsoft excel and SPSS software.

\section{RESULTS}

A total of 2932 FNACs was done between April 14, 2013 and April 13, 2014. Out of these, 333 cases were cystic lesions of head and neck. The age of patients ranged from 1 to 83 years (mean 35 years, median 31 years). Majority of the patients were in the age range 21-30 years (fig.1). Overall there were $186(56 \%)$ female patients and 147 (44\%) male patients with male to female ratio of 1:1.2 with a slight female predilection.

Most of the cysts were seen in the neck with 272 cases $(81.68 \%)$. Cysts in the neck are mostly seen in the lymph node $(31.9 \%)$ followed by thyroid $(28.3 \%)$. In head periauricular region was most common site with 15 cases of epidermal cyst and 8 cases of cyst originating in salivary gland.
Out of total 333 cases, 287 cases $(85.18 \%)$ were non neoplastic. Among the neoplastic cases 15 cases $(4.5 \%)$ were benign and 31 cases $(9.3 \%)$ were malignant (fig. 2 ).

Tuberculosis was the most common cause followed by colloid goiter with cystic change and epidermal cyst. Thyroid gland cystic lesions were more common in female ( 58 cases) than in male ( 16 cases) with male to female ratio of 1:3.6 (Table 1). Congenital cystic lesion comprises $9.3 \%$ of cystic lesions of head and neck with most of them occurring in first three decades of life. Majority of cases showed purulent aspirate $(26.42 \%)$ followed by colloid $(15.61 \%)$. Purulent aspirate was most common in tuberculosis $(n=44$; $50 \%)$ followed by abscess $(n=29 ; 32.9 \%)$ and squamous cell carcinoma $(n=8 ; 9.09 \%)$. There was concordance between FNAC diagnosis and histopathological diagnosis in 24/26 $(92.3 \%)$ cases while discordance was found in $2 / 26(7.69 \%)$ cases (Table 2).

In this study FNAC sensitivity in diagnosing malignant lesion was $83.3 \%$ and specificity $100 \%$. The false positive rate was $0 \%$ and false negative rate was $4.7 \%$. The positive predictive value was $100 \%$ and Negative predictive value was $95 \%$ (Table 3 ).

\section{DISCUSSION}

FNAC is an invaluable diagnostic tool to decide best line of management especially in malignant disease. It has become the predominant initial diagnostic technique for lesions at number of sites within head and neck.

The frequency of cyst was $11.35 \%$ of total material aspirated which was similar to study done by Dejmek et al. ${ }^{8}$ The age of patients ranged from 1 to 83 years (mean: 35 years and median: 31 years) with $\mathrm{M}: \mathrm{F}$ ratio of $1: 1.2$. Similar result was found by Firat et $\mathrm{al}^{2}$ with age ranging from $1-75$ years (mean age 36 years) and M:F ratio of 1.02:1. This has been attributed to increased hormonal activity associated with menstruation and childbearing. Periauricular region was most common site of involvement in head with epidermal cyst most common lesion in this site. This is in contrast to study be Al-Khateeb et $\mathrm{al}^{9}$ which showed epidermal cyst most common in neck.

In our study $85.18 \%$ of cases were non-neoplastic. This was in contrast to study by Firat et $\mathrm{al}^{2}$ which showed only $40 \%$ non-neoplastic lesions. This may be due to higher number of tuberculosis case in our region. Malignant cystic neoplasms were seen as early as second decade of life. This was due to greater percentage of papillary thyroid carcinoma which peaked in $2^{\text {nd }}-4^{\text {th }}$ decade of life. Similarly a study done by Ijomone EA et $\mathrm{al}^{10}$ showed papillary carcinoma was most common at age group 21-30 years. It is established that papillary carcinoma with RET/PTC rearrangement presents at younger age. ${ }^{11}$ 


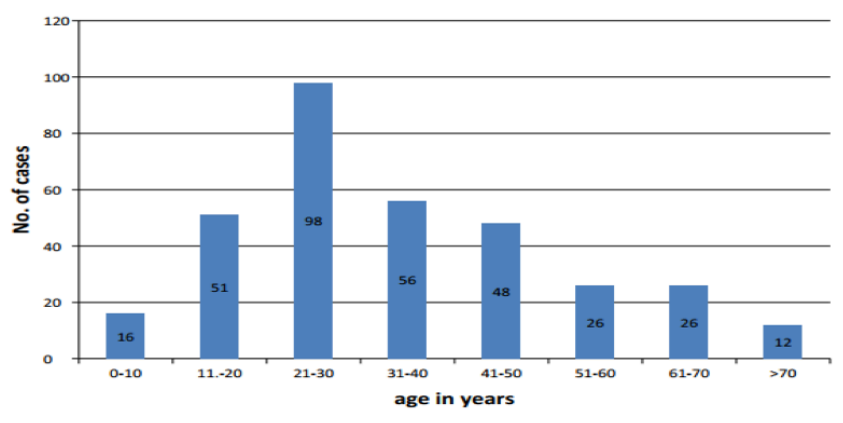

Figure 1: Age distribution of the patients.

Most of the congenital cysts were seen in first three decades of life with thyroglossal cyst being the most common one followed by dermoid cyst. This was in concordance with study done by Hsieh YY et al. ${ }^{12}$ Congenital cervical cysts are commonly encountered in pediatric population and results from embryonic structure that have failed to mature or have persisted in aberrant fashion. ${ }^{12}$

In our study tuberculous lymphadenitis $(21.02 \%)$ was most common lesion followed by colloid goiter with cystic change. Majority of patients; with tuberculous lymphadenitis; presented in third decade life with pus formation. In study

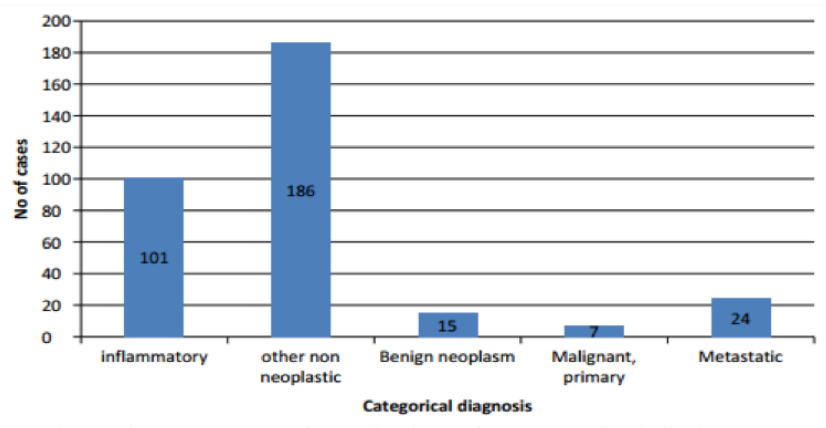

Figure 2: Frequency of neoplastic and non-neoplastic lesions

done by Maharjan $\mathrm{M}$ et $\mathrm{a}^{13}$ only $15 \%$ cases presented with pus formation and there was no difference observed between male and female. This discrepancy may have been observed because in our study we have only taken cases with cystic change. Tuberculous lymphadenitis is most common extrapulmonary form of tuberculosis and cervical lymph node are the most common affected group of lymph nodes. $^{14}$

Lymphangioma was the most common benign neoplastic lesion whereas papillary carcinoma of thyroid and squamous cell carcinoma were most common malignant

Table 1: Various FNAC diagnosis and characteristics of patients

\begin{tabular}{|c|c|c|c|c|}
\hline \multirow[t]{2}{*}{ FNAC Diagnosis } & \multicolumn{2}{|c|}{ Sex } & \multirow[t]{2}{*}{ Total } & \multirow[t]{2}{*}{ Percentage } \\
\hline & Female & Male & & \\
\hline Tuberculous lymphadenitis & 40 & 30 & 70 & 21 \\
\hline Colloid goitre with cystic change & 48 & 11 & 59 & 17.7 \\
\hline Epidermal cyst & 19 & 21 & 40 & 12 \\
\hline Benign cystic lesion & 18 & 14 & 32 & 9.6 \\
\hline Abscess & 12 & 17 & 29 & 8.7 \\
\hline Thyroglossal cyst & 9 & 6 & 15 & 4.5 \\
\hline Squamous cell carcinoma & 1 & 12 & 13 & 3.9 \\
\hline Papillary ca thyroid & 7 & 4 & 11 & 3.3 \\
\hline Retention cyst & 5 & 5 & 10 & 3 \\
\hline Lymphangioma & 6 & 3 & 9 & 2.7 \\
\hline Colloid cyst & 6 & 2 & 8 & 2.4 \\
\hline Branchial cyst & 3 & 4 & 7 & 2.1 \\
\hline Dermoid cyst & 2 & 4 & 6 & 1.8 \\
\hline Hemangioma & 2 & 2 & 4 & 1.2 \\
\hline Hematoma & 0 & 4 & 4 & 1.2 \\
\hline Spindle cell neoplasm & 2 & 1 & 3 & 0.9 \\
\hline Lymphoepithelial cyst (salivary gland) & 2 & 1 & 3 & 0.9 \\
\hline Mucoepidermoid ca & 0 & 2 & 2 & 0.6 \\
\hline Poorly differentiated ca & 1 & 1 & 2 & 0.6 \\
\hline Adenocarcinoma & 1 & 1 & 2 & 0.6 \\
\hline Pleomorphic adenoma with cystic change & 1 & 0 & 1 & 0.3 \\
\hline Warthins tumor & 0 & 1 & 1 & 0.3 \\
\hline Vascular lesion & 1 & 0 & 1 & 0.3 \\
\hline Suspicious of malignancy & 0 & 1 & 1 & 0.3 \\
\hline Total & 186 & 147 & 333 & 100 \\
\hline
\end{tabular}


Table 1: Various FNAC diagnosis and characteristics of patients

\begin{tabular}{|c|c|c|c|c|c|c|c|c|c|c|c|c|}
\hline \multirow[t]{2}{*}{$\begin{array}{c}\text { FNAC } \\
\text { Diagnosis }\end{array}$} & \multicolumn{11}{|c|}{ Histopathological diagnosis } & \multirow[t]{2}{*}{ Total } \\
\hline & EC & PC & TG & $\mathrm{BC}$ & $\mathrm{TB}$ & $\begin{array}{l}\text { Benigncys- } \\
\text { ticlesion }\end{array}$ & Dermoidcyst & Lym & CG & Schwannoma & Hemongioma & \\
\hline EC & 3 & & & & & & 1 & & & & & 4 \\
\hline PC & & 4 & & & & & & & & & & 4 \\
\hline CG & & & & & & & & & 4 & & & 4 \\
\hline TG & & & 3 & & & & & & & & & 3 \\
\hline TB & & & & & 3 & & & & & & & 3 \\
\hline $\begin{array}{l}\text { Benign cystic } \\
\text { lesion }\end{array}$ & & 1 & & & & 1 & & 1 & & & & 3 \\
\hline $\begin{array}{l}\text { Suspicious of } \\
\text { malignancy }\end{array}$ & & 1 & & & & & & & & & & 1 \\
\hline $\begin{array}{l}\text { Vascular } \\
\text { lesion }\end{array}$ & & & & & & & & & & & 1 & 1 \\
\hline BC & & & & 1 & & & & & & & & 1 \\
\hline Colloid cyst & & & & & & & & & 1 & & & 1 \\
\hline $\begin{array}{l}\text { Spindle cell } \\
\text { neoplasm }\end{array}$ & & & & & & & & & & 1 & & 1 \\
\hline Total & 3 & 6 & 3 & 1 & 3 & 1 & 1 & 1 & 5 & 1 & 1 & 26 \\
\hline
\end{tabular}

EC: Epidermal cyst, PC: Papillary carcinoma thyroid, TG: Thyroglossal cyst, BC: Branchial cyst, TB:

Tuberculosis, CG: Colloid goiter with cystic change, Lym: Lymphangioma

Table 3: Table for analysis of cytohistopathological correlation

\begin{tabular}{cccc}
\hline FNAC & \multicolumn{2}{c}{$\begin{array}{c}\text { HISTOPATHOLOGICAL } \\
\text { DIAGNOSIS }\end{array}$} & Total \\
DIANOSIS & Malignant & Benign & \\
Malignant & 5 & 0 & 5 \\
Benign & 1 & 20 & 21 \\
\hline Total & $\mathbf{6}$ & $\mathbf{2 0}$ & $\mathbf{2 6}$ \\
\hline
\end{tabular}

lesion. Moatamed et $\mathrm{al}^{7}$ also reported that papillary thyroid carcinoma and squamous cell carcinoma were most common non-salivary malignant cystic lesions in their study. Percentage of malignancy in cystic lesion of thyroid was $12.9 \%$ in female and $27.7 \%$ in males. This shows that thyroid swellings along with cystic lesions were more likely to be malignant in male patients.

Retention cyst was the commonest lesion in salivary gland. This was in discordance with study by Edwards PC, ${ }^{15}$ which showed Warthin's tumor to be the most common cystic lesion of salivary gland. This discrepancy may due to small number of cases of salivary gland and Warthin's tumor may have been misdiagnosed as benign cystic lesion in our study.

Two cases of papillary carcinoma of thyroid gland metastatic to cervical lymph node presented as cystic lesion, which were later diagnosed on histopathological examination. A case of papillary carcinoma of thyroid which presented as lateral neck cyst was also missed by another study done by Moatamed et $\mathrm{al}^{7}$. Therefore in a young patient with solitary lateral cyst the diagnosis of lymph node metastasis from papillary carcinoma should be considered.
A case with lateral cervical swelling on FNAC yielded 5 $\mathrm{ml}$ of yellowish fluid aspirate along with benign looking spindle cells. Diagnosis of benign spindle cell neoplasm was given which on biopsy revealed to be schwannoma. This shows that when lateral cervical cystic lesion is encountered a differential diagnosis of neurogenic neoplasm with cystic changes should be included. Bohara $\mathrm{S}$ et al ${ }^{16}$ reported a case with left neck mass masquerading as branchial cleft cyst clinically and radiologically; however histopathological examination showed it to be schwannoma.

In our study FNAC sensitivity in diagnosing malignant lesion was $83.3 \%$ and specificity was $100 \%$. The false positive rate was $0 \%$ and false negative rate was 4.7 percent. The positive predictive (PPV) was $100 \%$ and negative predictive value (NPV) was 95\%. Moatamed et al7 observed sensitivity of $76 \%$, specificity of $100 \%$, PPV of $100 \%$ and NPV of 92 percent. They had false positive rate of $0 \%$ and false negative rate of $6.5 \%$. Similarly, Firat P et $\mathrm{al}^{2}$ obtained sensitivity of $70 \%$ and specificity of 96 percent. The greater sensitivity in our study could be due to low number of cases in which both FNAC and histopathological examination were done.

\section{CONCLUSION}

FNAC is a very useful investigation which provides an accurate and cost-effective preoperative identification of cystic lesion of head and neck. A systematic approach coupled with an awareness of common pitfalls in diagnosis of cystic head and neck lesions can result in correct diagnosis in large number of cases. Sensitivity and specificity of FNAC in diagnosing the malignant lesion was significantly 
high making it an ideal first line of investigation.

\section{Conflict of interest: None}

\section{REFERENCES}

1. Shenoy, K.R., Tumors, Cysts, Neck swelling, in Manipal Manual of Surgery, K.R. Shenoy, Editor. 2005, CBS publishers and distributors: New Delhi. p157-205.

2. Firat P, Ersoz C, Uguz A, Onder S. Cystic lesions of the head and neck: cytohistological correlation in 63 cases. Cytopathol 2007;18:184-90. Crossref

3. Odile, D., B. Saad, and H. Matthew, Parotid Gland Fine-Needle Aspiration Cytology: an approach to differential diagnosis. Diagn Cytopathol 2007;35:47-56. Crossref

4. Schindler S1, Nayar R, Dutra J, Bedrossian CW. Diagnostic challange in aspiration cytology of the salivary glands. Semin Diagn Pathol 2001;18:124-46. Crossref

5. Sheahan P, O'leary G, Lee G, Fitzgibbon J. Cystic cervical metastases: incidence and diagnosis using fine needle aspiration biopsy. Otolaryngol Head Neck Surg, 2002;127:294-8. Crossref

6. Granstrom G, Edstrom S. The relationship between cervical cysts and tonsillar carcinoma in adults. J Oral Maxillofacial Surg, 1989;47:1620. Crossref

7. Moatamed NA, Naini BV, Fathizadeh P, Estrella J, Apple SK. A correlation study of diagnostic fine-needle aspiration with histologic diagnosis in cystic neck lesions. Diagn. Cytopathol 2009;37:720-6. Crossref
8. Dejmek A, Lindholm K. Fine needle aspiration biopsy of cystic lesions of the head and neck, excluding the thyroid. Acta Cytol 1990;34:443-8. Crossref

9. Al-Khateeb TH, Al-Masri NM, Al-Zoubi F. Cutaneous cysts of the head and neck. J Oral Maxillofac Surg, 2009;67:52-7. Crossref

10. Ijomone EA, Duduyemi BM, Udoye E, Nwosu SO. Histopathological review of thyroid diseases in southern Nigeria-a ten year retrospective study. Journal of Medicine and Medical Sciences, 2014;5:127-32.

11. Adeniran AJ, Zhu Z, Gandhi M, et al. Correlation between genetic alterations and microscopic features, clinical manifestations, and prognostic characteristics of thyroid papillary carcinomas. Am J Surg Pathol 2006; 30:216-22. Crossref

12. Hsieh YY, Hsueh S, Hsueh C, Lin JN, Luo CC, Lai JY, Huang CS. Pathological analysis of congenital cervical cysts in children: 20 years of experience at Chang Gung Memorial Hospital. Chang Gung Med J 2003;26:107-13. Crossref

13. Maharjan M, Hirachan S, Kafle PK, Bista M, Shrestha S, Toran KC, Lakhey M. Incidence of Tuberculosis in enlarged neck nodes, our experience. Kathmandu Univ Med J, 2009;7:54-8. Crossref

14. Sharma M, Agarwal S, Wadhwa N, Mishra K, Gadre DJ. Spectrum of cytomorphology of tuberculous lymphadenitis and changes during anti-tubercular treatment. Cytopathol 2007;18:180-3. Crossref

15. Edwards PC, Wasserman P. Evaluation of cystic salivary gland lesions by fine needle aspiration: an analysis of 21 cases. Acta Cytol 2005;49:489-94. Crossref

16. Bohara S, Dey D, Agarwal S, Gupta R, Khurana N, Gulati A. A case of cystic schwannoma in the neck masquerading as branchial cleft cyst. Rare Tumors 2014;6:5355. Crossref 